\title{
A Retrospective Evaluation of Patients with Recurrent Aphthous Stomatitis
}

\section{Rekürren Aftöz Stomatitli Hastaların Retrospektif Olarak Değerlendirilmesi}

\author{
Filiz Topaloğlu Demir, Mustafa Demir*, Zafer Türkoğlu, Nazlı Dizen Namdar** \\ Haseki Training and Research Hospital, Clinic of Dermatology, istanbul, Turkey \\ *Bartin State Hospital, Clinic of Ophthalmology, Bartın, Turkey \\ ${ }^{*}$ Dumlupınar University Faculty of Medicine, Department of Dermatology, Kütahya, Turkey
}

Abstract

Aim: To determine the factors in the etiology of recurrent aphthous stomatitis (RAS) and to evaluate patients in the terms of RAS associated systemic disorders especially Behçet's disease.

Methods: Patients with RAS, who were followed up in Bartın State Hospital Dermatology Clinic between July 2013 and April 2015, were retrospectively evaluated.

Results: A total of 123 patients (86 female, 37 male) were included in this study. Thirteen (106\%) patients were children. The mean age of patients was $34.5 \pm 14.7$ years (range: $8-69$ years). Minor aphthous somatitis was the most frequent clinical type (68.3\%). Family history was positive in $52.8 \%$ of patients. The triggering factors in the etiology of RAS were stress (54.5\%), trauma (40.2\%), gingivitis (29.3\%), food (9.8\%), medicines $(5.7 \%)$, menstruation in female patients $(3.3 \%)$, and throat infections (2.4\%). Nutritional deficiencies were found in $39 \%$ of patients. There was a statistically significant difference in attack frequency $(p=0.017)$ and throat infection history $(p=0.029)$ between adults and pediatric patients. Fourteen (11.4\%) patients were diagnosed with Behçet's disease. When we compared the RAS patients diagnosed with Behçet's disease and the other RAS patients, a significant difference was found in pathergy test $(p<0.001)$ and ferritin levels $(p=0.020)$.

Conclusion: Patients with RAS should be followed up for a long time for systemic disorders, especially for Behçet's disease, accompanying RAS.

Keywords: Aphthous stomatitis, oral ulcer, Behçet's disease
Amaç: Rekürren aftöz stomatit (RAS) tanısı ile takibe alınan hastalarda etiyolojide yer alan faktörleri belirlemek ve başta Behçet hastalığı olmak üzere RAS'la ilişkilendirilmiş sistemik hastalıklar açısından hastaları değerlendirmektir.

Yöntemler: Temmuz 2013 ve Nisan 2015 tarihleri arasında Bartın Devlet Hastanesi Dermatoloji Polikliniğìne başvuran, RAS tanısı alan hastalar retrospektif olarak değerlendirildi.

Bulgular: Toplam 123 hasta (86'sı kadın, 37'si erkek, yaş aralığı 8-69) çalışmaya dahil edildi. Yaş ortalaması 34,5 $\pm 14,7$ idi. En sık minör aft $(\% 68,3)$ saptandı. Aile öyküsü hastaların $\% 52,8^{\prime}$ inde pozitifti. RAS'li hastalarda etiyolojide yer alan tetikleyici faktörler; stres $(\% 54,5)$, travma $(\% 40,2)$, gingivit $(\% 29,3)$, yiyecekler $(\% 9,8)$, ilaçlar $(\% 5,7)$, kadın hastalarda menstruasyon $(\% 3,3)$ ve boğaz enfeksiyonu $(\% 2,4)$ olarak saptandı. Hastaların \%39'unda nütrisyonel eksiklik mevcuttu. RAS'li çocuk hastalar ile erişkin hastaları karşılaştırdığımızda atak sıklığı ve boğaz enfeksiyonu $(p=0,029)$ dışında istatistiksel açıdan anlamlı bir fark gözlenmedi. On dört hastaya $(\% 11,4)$ Behçet hastalığı tanısı konuldu. Behçet hastalığı tanısı alan hastalar ile diğer RAS'li hastaları kıyasladığımızda, paterji pozitifliği $(p<0,001)$ ve ferritin düzeyleri $(p=0,020)$ arasındaki fark istatiksel açıdan anlamlıydı.

Sonuç: RAS hastalarını sadece etiyolojik faktörler ve hematinik eksikler açısından değerlendirmek yeterli değildir. Bu hastalar başta Behçet hastalığı başta olmak üzere RAS'nin eşlik ettiği diğer sistemik hastalıklar açısından uzun süre takibe alınmalıdır.

Anahtar Sözcükler: Aftöz stomatit, oral ülser, Behçet hastalı̆ı

\section{Introduction}

Recurrent aphthous stomatitis (RAS) is the most common oral mucosal disease, characterized by chronic, painful, repetitive in character, round or oval, smooth- edged, and necrotizing ulcerations (1). Many factors, such as local, microbial, systemic, nutritional, genetic immunological and allergic, are blamed in the etiology but it is not yet fully understood (2). Behçet's disease, mouth and
Address for Correspondence/Yazışma Adresi: Filiz Topaloğlu Demir Haseki Training and Research Hospital, Clinic of Dermatology, İstanbul, Turkey E-mail: filizsvet@yahoo.com

Received/Geliş Tarihi: 06 April 2016 Accepted/Kabul Tarihi: 20 April 2016
${ }^{\circ}$ Copyright 2017 by The Medical Bulletin of Haseki Training and Research Hospital The Medical Bulletin of Haseki published by Galenos Yayınevi. •Telif Hakkı 2017 Haseki Eğitim ve Araştırma Hastanesi Haseki Tıp Bülteni, Galenos Yayınevi tarafından basıımıştır. 
genital ulcers with inflamed cartilage (MAGIC) syndrome, gastrointestinal disorders (Crohn's disease, ulcerative colitis and celiac disease), human immunodeficiency virus (HIV) infection, Sweet's syndrome, periodic fevers with aphthous stomatitis, pharyngitis, and adenitis (PFAPA) syndrome, and cyclic neutropenia are major systemic diseases which may be associated with RAS (3).

As therapeutic approach varies according to triggering factors, frequency of recurrence and concomitant systemic disease, RAS patients in our study were evaluated in terms of all these factors. Behçet's disease, if present, was noted as a concomitant condition.

\section{Methods}

A hundred twenty three patients, who were admitted to the dermatology clinic at Bartın State Hospital between July 2013 and April 2015 and diagnosed with RAS by history and clinical findings, were included in the study. Patients who had previously been diagnosed with Behçet's disease, oral colchicine users and those without aphthous stomatitis on clinical examination were excluded. Records of patients with the diagnosis of RAS were retrospectively analyzed. Data on age, gender, history of systemic disease, smoking and drug use, duration of the disease (in months), clinical type of the aphthous lesion, family history, and frequency of recurrence were noted. The patients were divided into 3 groups according to the frequency of attacks in a year $(\leq 5,6-9, \geq 10)$. The classification of aphthous lesions were based on lesion diameter (minor: $\leq 1 \mathrm{~cm}$, major: $>1 \mathrm{~cm}$ ) and clinical features. The patients were also evaluated for other triggering factors, such as trauma, food, beverages, stress, frequency of throat infection, gum and tooth disease, besides, menstruation, oral contraceptive use and pregnancy for the female patients. Hematological laboratory tests, such as hemogram, iron, iron binding, ferritin, vitamin B12, and folate were recorded. Laboratory values of $12-16 \mathrm{~g} / \mathrm{dL}$ (female) and $14-18 \mathrm{~g} / \mathrm{dL}$ (male) for hemoglobin, $11-306.8 \mathrm{ng} / \mathrm{mL}$ (female) and 23.9-336.2 ng/ $\mathrm{mL}$ (male) for serum ferritin, $2.33-17.24 \mathrm{ng} / \mathrm{mL}$ for folate and $126.5-505 \mathrm{pg} / \mathrm{mL}$ for vitamin B12 were considered normal. All patients were evaluated for RAS-associated systemic disorders, such as Behçet's disease, Reiter's syndrome, gastrointestinal systemic diseases (inflammatory bowel disease, celiac disease), immune disorders, MAGIC syndrome, periodic fever, aphthous stomatitis, pharyngitis, and cervical adenitis (PFAPA) syndrome, Sweet's syndrome, and cyclic neutropenia. Pathergy test was performed in all patients to evaluate Behçet's disease. History of genital ulcer, erythema nodosum, thrombophlebitis, papulopustular lesions and arthritis, clinical findings and biopsy results from suspicious lesions were recorded for all patients. Ophthalmologic examination was performed in all patients. The relevant clinics were consulted for patients having headache, stomachache, diarrhea, and joint pain.

\section{Statistical Analysis}

SPSS 15.0 for Windows was used for statistical analysis. Descriptive statistics; numbers and percentages for categorical variables, average, standard deviation, minimum and maximum were given for numeric variables. Categorical variable rates between groups were analyzed by chi-square test. When the condition could not be achieved in the case, the Bonferroni correction or Monte Carlo simulation were applied. Mann-Whitney $U$ test was used to compare the numerical variable of independent two-groups when the normal distribution condition was not provided. A p value of less than 0.05 was considered statistically significant.

\section{Results}

A total of 123 patients (86 female, 37 male) were included in this study. Thirteen (106\%) patients were children. Female/male ratio was 2.32 and the mean age of the patients was 34.5 \pm 14.7 years (range: 8-69 years). The mean duration of disease was $83.9 \pm 78.9$ months (range 4-360). Minor aphthous somatitis was the most frequent clinical type in RAS patients. Minor aphthous somatitis was seen in 84 patients (68.3\%), major somatitis in $24(19.5 \%)$, and both minor and major types were seen in 14 patients $(11.4 \%)$. Herpetiform type was seen in only one $(0.8 \%)$ patient (Figure 1, 2).

Family history was positive in 65 patients $(52.8 \%)$. Fifty-four patients $(43.9 \%)$ had positive family history in their first-degree relatives, seven (5.7\%) patients had this condition in their second-degree relatives and four (3.3\%) patients had positive history in both first-and seconddegree relatives. In our study, the mean duration of the disease was $102.2 \pm 86.2$ months in family history-positive patients and $63.5 \pm 64.6$ months in family history-negative patients. The relationship between family history and disease duration was statistically significant $(p=0.003)$.

When the adults patients were evaluated in terms of smoking, it was found that only nine (8.2\%) were smokers and $12(10.9 \%)$ have had stopped smoking. In two patients (1.8\%), RAS occurred after stopping smoking and in five patients (4.5\%), there was an increase in the frequency of oral aphthae after stopping smoking. Eightynine patients $(80.9 \%)$ were non-smokers. There was no significant difference in the number of attacks and clinical type of RAS between smokers, non-smokers and patients who stopped smoking.

When the relationship between RAS and traumatic events (such as bite, brushing teeth, chewing gum) was examined, trauma was detected to be the triggering factor in 49 patients (40.2\%). RAS was associated with 
stress in 67 patients (54.5\%). In seven patients (5.7\%), RAS was associated with non-steroidal anti-inflammatory drug (NSAID) use. There was a history of triggering with food in 12 patients (9.8\%). Spicy foods, citrus fruits and nuts were most commonly cited group for causing RAS. When we questioned the relationship between RAS and hormonal factors in adult female patients, we found that only four patients (3.6\%) reported the association between menstruation and RAS. Gingivitis was detected in 36 patients (29.3\%). While only three patients $(2.4 \%)$ reported frequent throat infection, one patient had hepatitis B and one patient had hepatitis C. HIV infection; cyclic neutropenia or any other diseases which can cause immunosuppression were not detected in our patients.

The mean hemoglobin $(\mathrm{Hb})$ level was $13.4 \pm 1.8 \mathrm{~g} /$ $\mathrm{dL}$. Anemia was detected in 33 patients $(26.8 \%)$. The

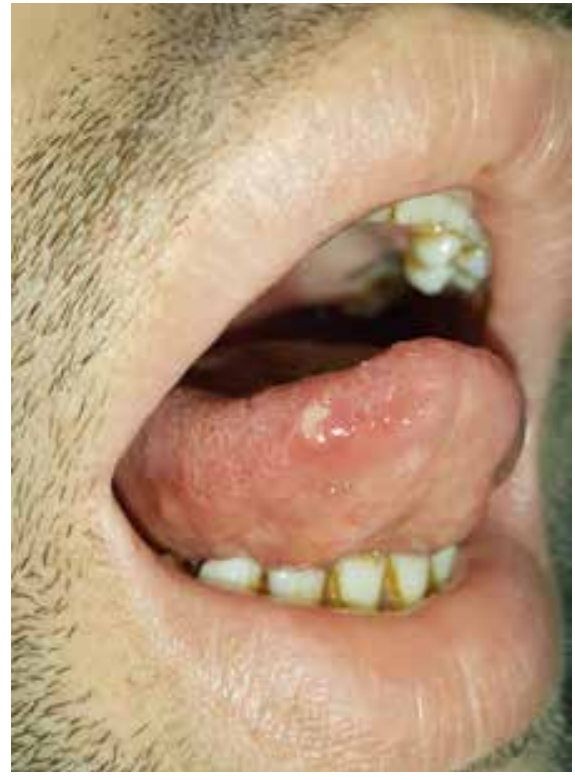

Figure 1. Minor aphthae

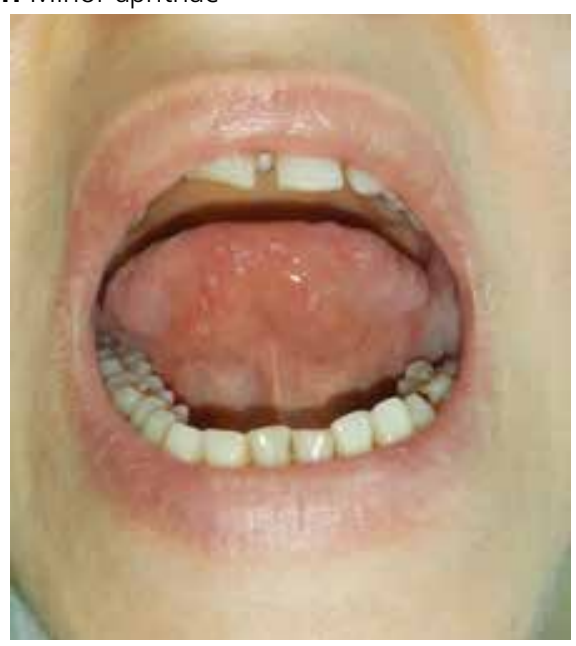

Figure 2. Herpetiform aphthae lowest $\mathrm{Hb}$ level was $9 \mathrm{~g} / \mathrm{dL}$. The mean serum iron level was $70.9 \pm 33.2 \mu \mathrm{g} / \mathrm{dL}$. Twelve patients $(9.8 \%)$ had low serum iron level. The mean ferritin level was found to be $50.6 \pm 77.9 \mathrm{ng} / \mathrm{mL}$. Ferritin level was low in 31 patients (25.2\%). The mean folate level was $12.0 \pm 20.3 \mathrm{ng} /$ $\mathrm{mL}$. Folate levels were normal in all patients. The mean vitamin B12 level was $273.7 \pm 168.4 \mathrm{pg} / \mathrm{mL}$. Seventeen patients (13.8\%) had low vitamin B 12 level. Both ferritin and vitamin B 12 deficiency were detected in four patients $(3.3 \%)$ and only three (2.4\%) patients had iron-deficiency anemia. There was no statistically significant difference between genders in terms of laboratory values. While $48 \%$ of patients had at least one pathology in the studied parameters, nutrition deficiency was found in 39\% of patients. When we compared pediatric and adult patients with RAS, we found no significant difference except for frequency of attacks $(p=0.017)$ and history of throat infection $(p=0.029)$ (Table 1).

While pathergy test was positive in 21 patients (17.1\%), genital ulcer was detected in seven (5.7\%) and genital scar was detected in two patients (1.6\%). Eritema nodosum was detected in four patients (3.3\%) and, two patients $(1.6 \%)$ had a history of eritema nodosum. Previous thrombophlebitis and deep vein thrombosis history was present in only one patient $(0.8 \%)$. Ten patients $(8.1 \%)$ had papulopustular lesions histologically consistent with Behçet's disease and 13 patients (10.6\%) had a history of papulopustular lesions which could be seen in Behçet's disease. There was no statistically significant relationship between pathergy test, trauma and papulopustular lesions. Arthralgia history was seen in 24 patients (19.6\%), however, there was only one patient $(0.8 \%)$ with arthritis detected on physical examination. Previous uveitis findings were present in two patients (1.6\%) (one anterior and one posterior uveitis). Headache history was found in 52 patients (42.3\%) but only one patient was diagnosed as having neuro-Behçet disease. Headache complaints in other patients were associated with migraine, tension headache and sinusitis. Abdominal pain and diarrhea were detected in 29 patients (23.6\%) but entero-Behçet's disease and any other gastrointestinal system disease were not observed in any patients. Fourteen patients (11.4\%) were diagnosed with Behçet's disease with these findings. When we compared RAS patients diagnosed with Behçet's disease and other RAS patients, we found that there was a significant difference in pathergy test $(p<0,001)$ and ferritin levels $(p=0.020)$ (Table 2$)$.

\section{Discussion}

RAS is an inflammatory disease of oral mucosa with unknown etiology which is characterized by painful, recurrent, single or multiple ulcerations (4). Although 
Table 1. Comparison of pediatric and adult patients with recurrent aphthous stomatitis

\begin{tabular}{|c|c|c|c|c|c|c|}
\hline & & \multicolumn{4}{|c|}{ RAS } & \multirow[b]{3}{*}{$\mathbf{p}$} \\
\hline & & \multicolumn{2}{|c|}{ Pediatrics } & \multicolumn{2}{|c|}{ Adults } & \\
\hline & & $\mathbf{n}$ & $\%$ & $\mathbf{n}$ & $\%$ & \\
\hline \multirow[t]{2}{*}{ Gender } & Female & 10 & 76.9 & 76 & 69.1 & 0.753 \\
\hline & Male & 3 & 23.1 & 34 & 30.9 & \\
\hline \multirow[t]{4}{*}{ Type of RAS } & Minor type & 10 & 76.9 & 74 & 67.3 & 0.580 \\
\hline & Major type & 1 & 7.7 & 23 & 20.9 & - \\
\hline & Herpetiform type & 0 & 0.0 & 1 & 0.9 & - \\
\hline & Both minor and major type & 2 & 15.4 & 12 & 10.9 & - \\
\hline \multirow[t]{3}{*}{ Attack frequency } & $\leq 5$ & 2 & 15.4 & 12 & 10.9 & 0.017 \\
\hline & $6-9$ & 5 & 38.5 & 13 & 11.8 & - \\
\hline & $\geq 10$ & 6 & 46.2 & 85 & 77.3 & - \\
\hline \multirow[t]{3}{*}{ Genital ulcer } & None & 13 & 100.0 & 101 & 91.8 & 1.000 \\
\hline & Genital ulcer (+) at visit & 0 & 0.0 & 7 & 6.4 & - \\
\hline & Scar form & 0 & 0.0 & 2 & 1.8 & - \\
\hline \multirow[t]{3}{*}{ Eritema nodosum } & None & 13 & 100.0 & 103 & 94.5 & 1.000 \\
\hline & Positive at first visit & 0 & 0.0 & 4 & 3.7 & - \\
\hline & Previous EN history & 0 & 0.0 & 2 & 1.8 & - \\
\hline \multirow[t]{3}{*}{ Pseudofolliculitis } & None & 11 & 84.6 & 89 & 80.9 & 1.000 \\
\hline & Positive at first visit & 1 & 7.7 & 9 & 8.2 & - \\
\hline & Previous PF history & 1 & 7.7 & 12 & 10.9 & - \\
\hline \multirow[t]{2}{*}{ Tromboflebitis } & None & 13 & 100.0 & 109 & 99.1 & 1.000 \\
\hline & Previous tromboflebitis & 0 & 0.0 & 1 & 0.9 & - \\
\hline \multirow[t]{2}{*}{ Pathergy } & Negative & 12 & 92.3 & 90 & 81.8 & 0.695 \\
\hline & Positive & 1 & 7.7 & 20 & 18.2 & - \\
\hline \multirow[t]{3}{*}{ Ocular involvement } & None & 13 & 100.0 & 108 & 98.2 & 1.000 \\
\hline & Anterior uveitis & 0 & 0.0 & 1 & 0.9 & - \\
\hline & Posterior uveitis & 0 & 0.0 & 1 & 0.9 & - \\
\hline Neuro Behçet's & - & 0 & 0.0 & 1 & 0.9 & - \\
\hline \multirow[t]{4}{*}{ Joint symptoms } & None & 12 & 92.3 & 86 & 78.2 & 0.827 \\
\hline & Artritis & 0 & 0.0 & 1 & 0.9 & - \\
\hline & Artralgia & 1 & 7.7 & 19 & 17.3 & - \\
\hline & Artritis ve artralgia history & 0 & 0.0 & 4 & 3.6 & - \\
\hline Family history & - & 6 & 46.2 & 59 & 53.6 & 0.609 \\
\hline \multirow[t]{4}{*}{ Family history } & None & 7 & 53.8 & 51 & 46.4 & 1.000 \\
\hline & $1^{\text {st }}$ degree relatives & 6 & 46.2 & 48 & 43.6 & - \\
\hline & $2^{\text {nd }}$ degree relatives positive & 0 & 0.0 & 7 & 6.4 & - \\
\hline & $1^{\text {st }}$ and $2^{\text {nd }}$ degree relatives RAS history & 0 & 0.0 & 4 & 3.6 & - \\
\hline Gingivitis & - & 1 & 7.7 & 35 & 31.8 & 0.106 \\
\hline Stress & - & 4 & 30.8 & 63 & 57.3 & 0.070 \\
\hline Trauma & - & 4 & 30.8 & 45 & 41.3 & 0.465 \\
\hline Throat infection & - & 2 & 15.4 & 1 & 0.9 & 0.029 \\
\hline Food allergy & - & 1 & 7.7 & 11 & 10.0 & 1.000 \\
\hline Drugs & - & 0 & 0.0 & 7 & 6.4 & 1.000 \\
\hline Menstruation & - & 0 & 0.0 & 4 & 3.6 & 1.000 \\
\hline
\end{tabular}




\begin{tabular}{|c|c|c|c|c|c|c|}
\hline & & \multicolumn{4}{|c|}{ RAS } & \multirow[b]{3}{*}{$\mathbf{P}$} \\
\hline & & \multicolumn{2}{|c|}{ Pediatrics } & \multicolumn{2}{|c|}{ Adults } & \\
\hline & & $\mathbf{n}$ & $\%$ & $\mathbf{n}$ & $\%$ & \\
\hline Behçet's disease & & 0 & 0.0 & 14 & 12.7 & - \\
\hline \multirow[t]{2}{*}{ Hemoglobin } & Normal & 10 & 76.9 & 80 & 72.7 & 1.000 \\
\hline & Low & 3 & 23.1 & 30 & 27.3 & - \\
\hline \multirow[t]{2}{*}{ Iron } & Normal & 12 & 92.3 & 99 & 90.0 & 1.000 \\
\hline & Low & 1 & 7.7 & 11 & 10.0 & - \\
\hline \multirow[t]{2}{*}{ Ferritin } & Normal & 11 & 84.6 & 81 & 73.6 & 0.514 \\
\hline & Low & 2 & 15.4 & 29 & 26.4 & - \\
\hline \multirow[t]{2}{*}{ Vitamin B12 } & Normal & 10 & 76.9 & 96 & 87.3 & 0.388 \\
\hline & Low & 3 & 23.1 & 14 & 12.7 & - \\
\hline
\end{tabular}

seen in both genders, RAS is detected more frequently in female gender (5). The majority of RAS patients were female in our study similar to that in other studies $(6,7)$. Minor aphthae is the most frequent clinical form which seen in $75-85 \%$ of RAS patients. Minor aphthae form is followed by major aphthae form (10-15) and herpetiform aphthae (5-10\%) (8). Generally, patients have only one clinical type of the disease. Nevertheless, it has been reported that two separate clinical types can be found at the same time (9). In their including 100 patients with RAS, Bahalı et al. (6) reported that 88 patients (88\%) had minor aphthae, 10 patients (10\%) had minor and major aphthae and two patients (2\%) had minor and herpetiform aphthae. Although minor aphthae rate was lower in our study than in the literature, it was still the most frequent RAS type. While major aphthae rate was higher than in the literature, herpetiform aphthae rate was lower. In addition,

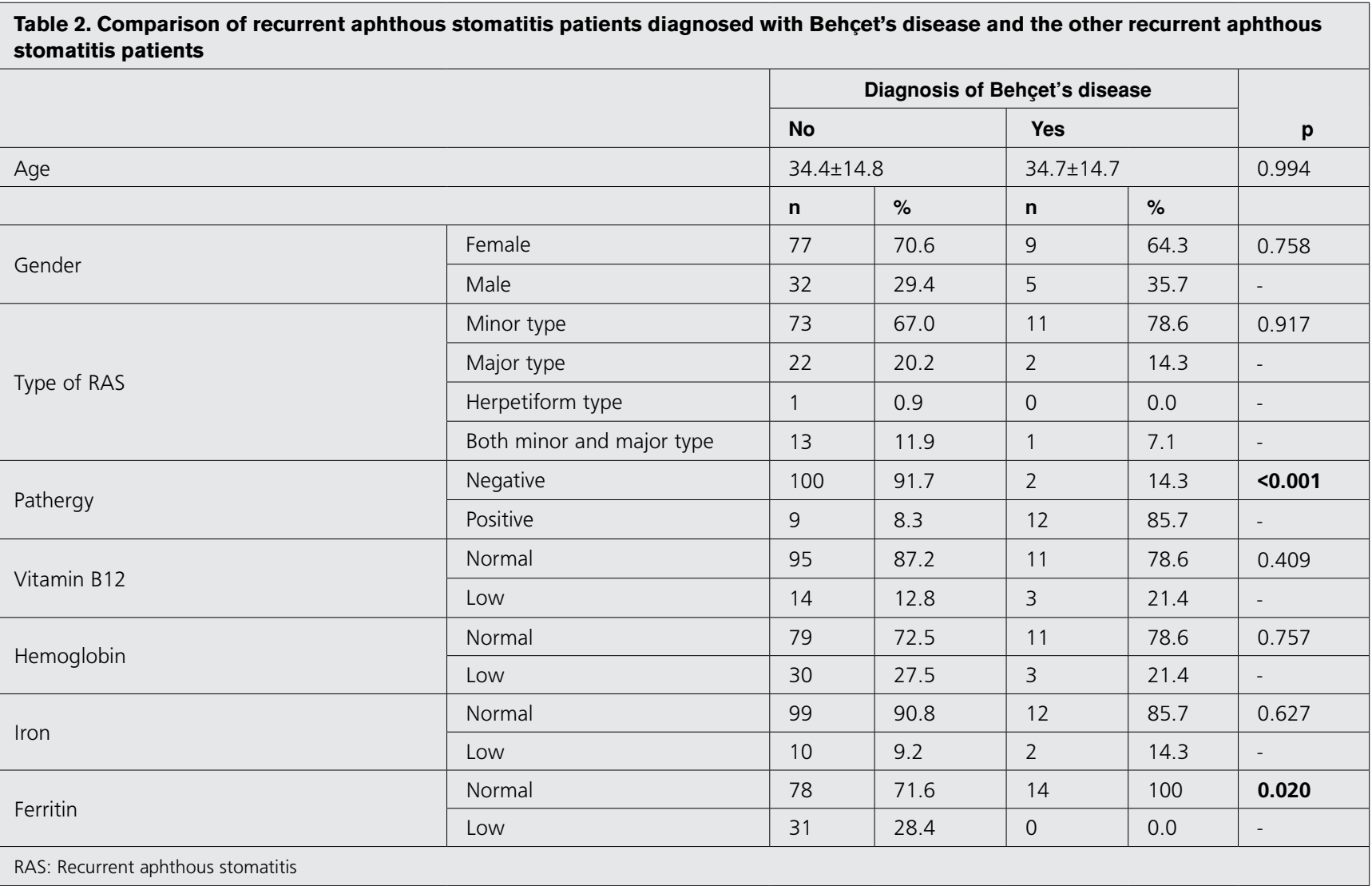


minor and major aphthae were observed at the same time in $11.4 \%$ of patients.

The presence of family history has been identified as a risk factor affecting the disease progression and the clinical course in RAS patients. In the literature, positive family history was determined in 42 to $67.3 \%$ of patients (10-12). In our study, consistent with the literature, positive family history was determined in $52.8 \%$ of patients. Disease duration was longer in patients with positive family history, but there was no relationship of positive family history, with clinical form and attack frequency. These findings were different from the literature showing the association between family history and disease severity $(13,14)$.

It has been reported that RAS is rare in smokers. This preventive effect of smoking is associated with oral mucosal keratinization, which is seen in smokers, and antiinflammatory effect of nicotine $(15,16)$. Only $8.2 \%$ of the patients in our study were smoker. RAS occurred after stopping smoking in two patients and frequency of RAS increased after stopping smoking in five patients. These results indirectly support the protective activity of smoking on RAS.

Some triggering factors are blamed in the development of RAS. Filiz et al. (17) reported in their study including 39 patients with RAS and 36 healthy controls, that oral aphthae were associated with trauma in 12.8 of subjects, with foods in $15.3 \%$, with stress in $66.6 \%$ and with menstruation in $8.6 \%$ of subjects. Bahalı et al. (6) reported that RAS was associated with bite (12\%), brushing teeth $(18 \%)$, the presence of dental disease $(82 \%)$, food (39\%), menstruation (10.3\%) and stress (76\%). Also in their study on 30 RAS patients and 49 patients with Behçet's disease, Gungor et al. (7) reported that oral aphtae were associated with trauma in $30 \%$ of subjects, with stress in $60 \%$ and with menstruation in $10 \%$ of female patients. In our study, we found that RAS was associated with trauma in $40.2 \%$, with food in $9.8 \%$, with stress in $54.5 \%$ of patients and with menstruation in $3.6 \%$ of female patients. The main drugs that can cause aphthouslike lesions are NSAIDs, $\beta$-blockers, captopril, gold salts, nicorandil, niflumic acid, phenindione, phenobarbital, piroxicam, and sodium hypochlorite (18). In our study, RAS was associated with drugs (NASIDs) in $5.7 \%$ of patients. The patients confirmed that they often used NSAIDs for various reasons and after usage, oral aphthae occurred. Some authors reported that microbiological mechanisms can cause RAS (8). In this respect, it has been suggested that oral streptococci could play a role in the pathogenesis of RAS (19). In our study, only three patients (2.4\%) had a history of frequent throat infections and only one of them was group A beta-hemolytic streptococci-positive in throat culture.
Nutritional deficiencies may play a role in the etiology of RAS. In a study by Solak et al. (20), hematological changes were detected in $61.8 \%$ of RAS patients. In that study $30 \%$ of patients had anemia, 26.3\% had vitamin B12 deficiency and $25.4 \%$ of patients had ferritin deficiency. Bahalı et al. (6) in their study examining the relationship between RAS and hematinic deficiencies, reported that 16 patients (16.7\%) had only iron deficiency, 22 patients $(22.4 \%)$ had only vitamin B12 deficiency and four patients (4.3\%) had both iron and vitamin B12 deficiency; ferritin levels were low in 18 patients (18\%) and folat levels were normal in all patients. Compilato et al. (21) reported that $56 \%$ of RAS patients had pathological values with hematologic tests, therefore, they suggested that in all RAS patients hematological tests must be done and deficiencies must be treated. This rate was determined as $26 \%$ in a study by Barnadas et al. (22). In our study, we detected anemia in $26.8 \%$ of patients, vitamin B12 deficiency in $13.8 \%$, low ferritin levels in $25.2 \%$, and low serum iron levels in $9.8 \%$ of patients. Folat deficiency was not observed. While $3.3 \%$ of patients had both ferritin and vitamin B12 deficiency, only $2.4 \%$ of patients had iron-deficiency anemia. Pathology was detected in at least one of the studied parameters in $48 \%$ of patients, and also nutritional deficiency was detected in $39 \%$ of patients. Although the relationship between RAS and hematinic deficiency is still uncertain, especially vitamin B12, ferritin and iron deficiency should be investigated and treated.

In our study, $10.6 \%$ of patients were children. This finding made us to think that child patients may be admitted to pediatric clinics for RAS instead of dermatology clinics. When we compare these patients with adult patients, we found no significant difference between them except for attack frequency and throat infection history.

It is known that RAS can be related with many systemic diseases such as Behçet's disease, MAGIC syndrome, Crohn's disease, ulcerative colitis, celiac disease and cyclic neutropenia (3). In our study, we did not find any systemic disease in RAS patients except for Behçet disease. Oral ulcerations which are major criteria for Behçet's and ulcerations that seen in RAS patients cannot be differentiated clinically and the number of relevant studies in the literature is limited $(23,24)$. Gungor et al. (7) reported that Behçet's disease began at an earlier age than RAS and, duration of the disease was longer in Behçet's disease. They found no statistically significant difference in family history between patients with Behçet's disease and RAS. The authors attributed this result to genetic factors that could play a role in the immunopathogenesis of both diseases. In a study by Main and Chamberlain (25), a statistically significant difference 
was not detected between patients with Behçet's oral ulceration and conventional oral ulceration with respect to onset of illness, age, family history, frequency and duration of oral ulcers. In our study, Behçet's disease was detected in $11.4 \%$ of patients who were admitted with RAS. There was no statistically significant difference between patients with Behçet's disease and those with RAS in terms of age, gender, duration of the disease, attack frequency and family history. Positive pathergy test was observed in $85.7 \%$ of Behçet's disease patients; this rate was $8.3 \%$ in RAS patients. Ferritin levels were normal in Behçet's patients but $28.4 \%$ of RAS patients had low ferritin levels. The difference in pathergy test positivity and ferritin levels was statistically significant. Aphthous lesions are the most common symptom of Behçet's disease and may continue 6-8 years in some patients before the diagnosis is established $(23,24)$. In the study of Bang and colleagues which followed up 67 patients presenting with recurrent oral ulcers, $52.2 \%$ of patients were diagnosed with Behçet's disease for an average of 7.7 years (24). In our study, the proportion of patients diagnosed with Behçet's disease was low compared to the literature because of the short follow-up period.

\section{Conclusion}

In conclusion, genetic features and predisposing factors such as trauma, stress, microbial factors, food, drug reactions, immune disorders, hormonal imbalances, and hematinic deficiencies may play a role in the etiology of RAS. RAS is also associated with many of the systemic disorders, mainly Behçet's disease. As a result, family history, clinical findings and laboratory results are not enough to classify ulcers according to systemic disorders. Patients with ongoing aphthae should be followed for a long time in terms of systemic disorders, especially Behçet's disease.

\section{Ethics}

Ethics Committee Approval: Retrospective study.

Peer-review: Externally peer-reviewed.

\section{Authorship Contributions}

Surgical and Medical Practices: Filiz Topaloğlu Demir. Concept: Filiz Topaloğlu Demir. Design: Filiz Topaloğlu Demir. Data Collection or Processing: Filiz Topaloğlu Demir. Mustafa Demir. Analysis or Interpretation: Filiz Topaloğlu Demir, Mustafa Demir, Nazlı Dizen Namdar. Literature Search: Filiz Topaloğlu Demir, Zafer Türkoğlu. Writing: Filiz Topaloğlu Demir.

Conflict of Interest: No conflict of interest was declared by the authors.

Financial Disclosure: The authors declared that this study received no financial support.

\section{References}

1. Odom RB, James WD, Berger TG. Recurrent aphthous stomatitis. Andrews' disease of the skin. 9th ed. Philedephia: WB Saunders Company; 2000.p.1006-8.

2. Ship JA. Recurrent aphthous stomatitis: An update. Oral Surg Oral Med Oral Pathol Oral Radiol Endod 1996;81:141-7

3. Scully $C$, Porter $S$. Oral mucosal disease: recurrent aphthous stomatitis. Br J Oral Maxillofac Surg 2008;46:198-206.

4. Graykowski EA, Barile MF, Lee WB, Stanley HR Jr. Recurrent aphthous stomatitis. Clinical, therapeutic, histopathologic, and hypersensitivity aspects. JAMA 1966;196:637-44.

5. Hutton KP, Rogers RS 3rd. Recurrent aphthous stomatitis. Dermatol Clin 1987;5:761-8.

6. Bahalı AG, Kokturk A, Guvenc U. Sociodemographic and clinical characteristics of patients with recurrent aphthous stomatitis. Turkderm 2014;48:242-8.

7. Gungor S, Akbay G, Eksioglu M. Clinical Comparison of Aphthae in Recurrent Aphthous Stomatitis and Behçet's Disease. Turkderm 2010;44:150-2.

8. Scully C, Porter S. Recurrent aphthous stomatitis: current concepts of etiology, pathogenesis and management. J Oral Pathol Med 1989;18:21-7.

9. Vanhale HM, Rogers RS, Doyle JA, Schroeter Al. Immunofluorescence microscopic studies of recurrent aphthous stomatitis. Arch Dermatol 1981;117:779-81.

10. McCullough MJ, Abdel-Hafeth S, Scully C. Recurrent aphthous stomatitis revisited; clinical features, associations, and new association with infant feding practices? J Oral Pathol Med 2007;36:615-20.

11. Safadi RA. Prevalence of recurrent aphthous ulceration in Jordanian dental patients. BMC Oral Health 2009;9:3.

12. Shohat-Zabarski R, Kalderon S, Klein T, Weinberger A. Close association of HLA-B51 in persons with recurrent aphthous stomatitis. Oral Surg Oral Med Oral Pathol 1992;74:455-8.

13. Miller MF, Garfunkel AA, Ram CA, Ship II. The inheritance of recurrent aphthous stomatitis. Observations on susceptibility. Oral Surg Oral Med Oral Pathol 1980;49:409-12.

14. Ship II. Inheritance of aphthous ulcers of the mouth. J Dent Res 1965;44:837-44.

15. Tüzün $B$, Wolf $R$, Tüzün $Y$, Serdaroğlu $S$. Recurrent aphthous stomatitis and smoking. Int J Dermatol 2000;39:358-60.

16. Scully C, Gorsky M, Nur FL. Aphthous ulcerations. Dermatologic Therapy 2002;15:185-205.

17. Filiz EE, Öztürkcan $S$, Yüceyar $H$, Kandiloğlu AR, Şendil AZ. Rekürren aftöz stomatit etiyolojisinde Helikobakter pilorinin rolü. Turkiye Klinikleri J Dermatol 2002;12:61-5.

18. Natah SS, Konttinen YT, Enattah NS, Ashammakhi N, Sharkey KA, Häyrinnen-Immonen R. Recurrent aphthous ulcers today: a review of the growing knowledge. Int I Oral Maxillofac Surg 2004;33:221-34.

19. Francis TC, Oppenheim JJ. Impaired lymphocyte stimulation by some streptococcal antigens in patients with recurrent aphthous stomatitis and rheumatic heart disease. Clin Exp Immunol 1970;6:573-86. 
20. Solak TN, Aydemir S, Sezer T, Duysak S, Altınyazar HC Rekürren aftöz stomatitli hastalarda hematolojik değişiklikler. Turkiye Klinikleri J Dermatol 2007;17:150-4.

21. Compilato D, Carroccio A, Calvino F, Di Fede G, Campisi G. Haematological deficiencies in patients with recurrent aphthosis. J Eur Acad Dermatol Venereol 2010;24:667-73.

22. Barnadas MA, Remacha A, Condomines J, de Moragas JM. Hematologic deficiencies in patients with recurrent oral aphthae. Med Clin (Barc) 1997;109:85-7.
23. Verpilleux MP, Bastuji-Garin S, Revuz J. Comparative analysis of severe aphthosis and Behçet's disease: 104 cases. Dermatology 1999;198:247-51.

24. Bang D, Hur W, Lee ES, Lee S. Prognosis and clinical relevance of recurrent oral ulceration in Behçet's disease. J Dermatol 1995;22:926-9.

25. Main DM, Chamberlain MA. Clinical differentiation of oral ulceration in Behçet's disease. Br J Rheumatol 1992;31:76770. 